\title{
PENGARUH REBUSAN BUNGA ROSELLA TERHADAP PENURUNAN TEKANAN DARAH (HIPERTENSI) PADA PASIEN DI WILAYAH KERJA PUKESMAS SUKAMERINDU BENGKULU
}

\author{
The Effect of Rosella Stew to Decreasing of Blood Pressure (Hypertension) in \\ Patients at Working Area of Sukamerindu Public Health Center Bengkulu
}

\author{
Vellyza Colin ${ }^{1}$, Buyung Keraman ${ }^{2}$, Evan Aditya Pratama ${ }^{1}$ \\ ${ }^{1}$ Program Studi Ilmu Keperawatan STIKES Tri Mandiri Sakti Bengkulu \\ ${ }^{2}$ Program Studi Matematika Fakultas MIPA Universitas Bengkulu \\ Email : vellyzacolin7@gmail.com
}

\begin{abstract}
ABSTRAK
Pengaruh rebusan bunga rosella terhadap penurunan tekanan darah (Hipertensi) pada pasien diwilayah kerja Puskesmas Sukamerindu Bengkulu. Hipertensi adalah peningkatan tekanan darah sistolik lebih dari $140 \mathrm{mmHg}$ dan diastolik lebih dari $90 \mathrm{mmHg}$. Penelitian ini bertujuan untuk mempelajari pengaruh rebusan bunga rosella digunakan untuk menurunkan tekanan darah oleh sebagian masyarakat. Penelitian ini merupakan penelitian kuantiatif dengan desain pra exsprimental. Populasi dalam penelitian ini pasien hipertensi yang berobat di Puskesmas Sukamerindu Kota Bengkulu pada bulan Januari-Desember 2018 sebanyak 52 orang dewasa yang terkena hipertensi. Teknik pengambilan sample dengan total sampling dengan kriteria inkulasi dan ekslusi sehingga sample yang diambil 30 orang yang memenuhi kriteria dalam pemberian rebusan bunga rosella dan 22 orang yang tidak memenuhi kriteria dalam pemberian bunga rosella untuk penurunan tekanan darah hipertensi. Pengumpulan data dalam penelitian ini menggunakan data sekunder dengan melihat cacatan dokumentasi di Poli Umum Di Puskesmas Sukamerindu Bengkulu.Hasil penelitian didapatkan: uji statistik Wilcoxon Sign Rank Test Hasil tekanan darah sistolik sebelum dan sesudah perlakuan didapatkan nilai $Z=-4,293$ dengan $p=$ value $=0,000<0,05$ berarti signifikan, maka Ho ditolak dan Ha diterima. Jadi Ada pengaruh pemberian rebusan bunga rosella terhadap penurunan tekanan darah sistolik pada pasien diwilayah kerja Puskesmas Sukamerindu Kota Bengkulu. Hasil tekanan darah diastol sebelum dan sesudah perlakuam didapatkan nilai $Z=-3,075$ dengan $p=$ value $=0,002<0,05$ berarti signifikan, maka Ho ditolak dan Ha diterima. Jadi Ada pengaruh pemberian rebusan bunga rosella terhadap penurunan tekanan darah diastolik pada pasien diwilayah kerja Puskesmas Sukamerindu Kota Bengkulu.
\end{abstract}

Kata Kunci : hipertensi, tekanan darah, rebusan rosella

\begin{abstract}
Effect of rosella stew on blood pressure (hypertension) reduction in patients in the Pukesmas area Sukamerindu Bengkulu. Hypertension is an increase in systolic blood pressure of more than $140 \mathrm{mmHg}$ and diastolic of more than $90 \mathrm{mmHg}$. This study discusses the benefits of rosella stew used for reducing blood pressure
\end{abstract}


by most people. This research is a quantitative research with pre-exemplary design. The population in this study were hypertensive patients seeking treatment at the Sukamerindu Public Health Center in Bengkulu City in January-December 2018 as many as 52 adults affected by hypertension. Sampling technique with total sampling with inclusion and exclusion criteria so that the samples taken were 30 people who met the criteria in the provision of rosella stew and 22 people who did not meet the criteria for rosella stew for decreasing hypertension. Data collection in this study uses secondary data by looked at documentation records at Puskesmas Sukamerindu Bengkulu.The results of this study showed: Wilcoxon Sign Rank Test statistical test Results of systolic blood pressure before and after treatment obtained a value of $Z=-4.293$ with $p=$ value $=0.000<0.05$ means significant, then $\mathrm{Ho}$ is rejected and $\mathrm{Ha}$ is accepted. So there is Effect of rosella stew to Decreasing of blood pressure (hypertension) in patients at area of Pukesmas Sukamerindu Bengkulu. The results of diastolic blood pressure before and after the treatment showed that the value of $Z=-3.075$ with $p=$ value = $0.002<0.05$ means significant, then Ho was rejected and Ha was accepted. So there is Effect of rosella stew to Decreasing of blood pressure (hypertension) in patients at area of Pukesmas Sukamerindu Bengkulu.

Keywords: blood pressure, hypertension, rosella stew

\section{A. Pendahuluan}

Menurunkan tekanan darah (hipertensi) merupakan masalah global didunia. Badan kesehatan dunia WHO menetapkan hipertensi sebagai faktor nomor tiga penyebab kematian di dunia. Hipertensi bertanggung jawab terhadap $62 \%$ timbulnya kasus stroke dan $49 \%$ timbulnya serangan jantung. Tujuh juta kematian prematur tiap tahun disebabkan oleh hipertensi.Menurut hipertensi merambah hampir kesemua golongan masyarakat seluruh dunia.Jumlah penderita hipertensi terus bertambah (Adi, 2013).

Hipertensi dikenal secara umum sebagai penyakit kardiovaskular. Penyakit ini diperkirakanmenyebabkan $4,5 \%$ dari beban penyakit secara global dan prevalensinya hampir sama besar di negara berkembang maupun di negara maju (WHO,2003). Data Global Status Report on Noncommunicable Diseases tahun 2010 dari WHO menyebutkan, $40 \%$ negara ekonomi berkembang memiliki penderita hipertensi, sedangkan negara maju hanya 35\%. Di kawasan Asia Tenggara, $36 \%$ orang dewasa menderita hipertensi.

Revelensi hipertensi di Indonesia berdasarkan hasil pengukuran menurut usia $>18$ tahun sebesar 25,8\%. Prevelensi hipertensi di Indonesia yang di peroleh melalui kuesioner terdiagnosis tenaga kesehatan adalah 9,4\% yang di diagnosis tenaga kesehatan sebesar atau sedang minum obat sebesar $9,5 \%$. Jadi terdapat $0,1 \%$ yang minum obat sendiri. Responden yang mempunyai tekanan darah normal tetapi sedang minum obat hipertensi sebesar $0,7 \%$. Jadi prevelensi hipertensi di Indonesia sebesar 26,5\% (Kemenkes RI, 2013).

Hakekat pembangunan Nasional adalah pembangunan seluruh rakyat Indonesia seutuhnya dan meningkatkan pengetahuan, kesadaran dan kemauan untuk mencapai hidup sehat setiap penduduk agar terwujud tujuan Nasional Indonesia sehat 2010. Di Provinsi Bengkulu pembangunan di 
bidang kesehatan dengan visi Bengkulu sehat 2010 antara lain dengan "mendorong peran serta aktif pemerintah, swasta dan masyarakat mewujudkan kemandirian dalam melakukan peningkatan kesehatan sehingga tercapai kesehatan masyarakat yang optimal" (Dinkes Provinsi Bengkulu, 2010).

Tanamanrosela hanya mengalami satu kali masa produktif. Tanaman ini menghasilkan bunga pada umur 120 hari dan dapat dipanen secara terus menerus dalam jangka waktu 3 bulan sebelum akhirnya diganti bibit baru. Tanaman ini dapat ditanam di halaman rumah, pekarangan dan sawah. Bibit rosela berupa biji dapat diperoleh di toko pertanian dengan harga yang relatif murah yaitu $\mathrm{Rp}$ $15.000 / \mathrm{kg}$ untuk penanaman lahan $2000 \mathrm{~m}$. Kebutuhan rosela yang semakin meningkat maka munculah berbagai strategi untuk memenuhi kebutuhan pasar.Salah satu strategi tersebut adalah dibentuknya plasma petani rosela. Sistem plasma ini dilakukan oleh para pengepul dengan merekrut para petani yang mempunyai lahan. Benih rosela diberi oleh para pengepul dan hasil panen harus dijual kepada pengepul. Rosela yang layak dijual kepada pengepul adalah rosela yang kering, utuh dan tidak busuk. Sistem plasma ini banyak dijalankan di daerah yang mayoritas petani.

Akhir-akhir ini Rosela telah mulai banyak dikembangkan di perkebunan-perkebunan dalam skala yang cukup besar.Di Indonesia telah ada beberapa perusahaan yang membudidayakan dan memasarkannya dalam bentuk teh celup atau the tubruk bunga kering (Maryani \& Kristiana. 2005).
Rumusan masalah dalam penelitian ini adalah "Apakah ada Pengaruh Rebusan Bunga Rosella Terhadap Penurunan Tekanan Darah pada pasien di wilayah Kerja Puskesmas Sukamerindu Bengkulu?. Tujuan dari penelitian ini adalah Untuk mempelajari "Pengaruh Rebusan Bunga Rosella Terhadap Penurunan Tekanan Darah pada pasien di wilayah Kerja Puskesmas Sukamerindu Bengkulu.

\section{B. Metode Penelitian}

Lokasi penelitian telah dilakukan di Puskesmas Sukamerindu Kota Bengkulu, waktu penelitian mulai pada bulan Juli 2019. Desain penelitian dalam penelitian ini menggunakan jenis penelitian kuantitatif, jenis penelitian ini merupakan jenis penelitian pra exsprimental dengan rancangan One Group Pre Test dan Post Test Coding. Populasi pada penelitian ini adalah obyek/subyek yang ada di Puksesmas Sukamerindu Bengkulu yang mengalami tekanan darah tinggi (hipertensi) dalam kategori hipertensi ringan dan berat yang memiliki tekanan darah tinggi di Puskesmas Sukamerindu kota Bengkulu.Dengan besar sampel 30 sampel. Teknik pengambilan sampel menggunakan metode Total sampling. Teknik Pengumpulan Data menggunakan Data primer dan Data sekunder. Teknik Analisis Data menggunakanUji Normalitas, Analisa univariat dan Analisa bivariate. Analisa bivariate digunakan untuk mengetahui penyebab rebusan bunga rosella atau menyelidiki pengaruh penurunan tekanan darah di wilayah kerja Puskesmas Sukamerindu Kota Bengkulu dengan menggunakan uji statistik Paired Sample T-Test, jika data berdistribusi normal, sedangkan 
jika data tidak berdistribusi normal maka akan menggunakan Wilcoxon Signed Rank Test dengan tingkat bermakna $\alpha \leq 0,05$. Etika dalam penelitian ini ditekankan pada Informed Consent, Anonimity, dan Confidentialy

\section{Hasil Penelitian}

\section{Analisis Univariat}

Analisis ini dilakukan untuk tiap-tiap variabel yang diteliti dari hasil penelitian yang kemudian akan mendapatkan hasil dari pengaruh pemberian rebusan bunga rosella terhadap penurunan tekanan darah

Tabel 1

Gambaran Penurunan Tekanan Darah Sebelum Perlakuan di Puskesmas Sukamerindu

\begin{tabular}{llcc}
\hline No & Tekanan Darah & Frekuensi & Persentase (\%) \\
\hline 1 & Pre Hipertensi & 1 & 3,3 \\
2 & Hipertensi Tahap 1 & 19 & 63,3 \\
3 & Hipertensi Tahap 2 & 10 & 33,3 \\
\hline \multicolumn{2}{l}{ Total } & 30 & $99,9(100,0)$ \\
\hline
\end{tabular}

Berdasarkan Tabel 1 diatas hipertensi tahap 1 sebanyak 19 orang dapat diketahui bahwa dari $30 \quad(63,3 \%)$ dan hipertensi tahap 2 responden di Puskesmas Sukamerindu sebanyak 10 orang $(33,3 \%)$. yang memiliki tekanan darah pre hipertensi sebanyak 1 orang $(3,3 \%)$,

Tabel 2

Gambaran Penurunan Tekanan Darah Sesudah Perlakuan di Puskesmas Sukamerindu

\begin{tabular}{llcc}
\hline No & Tekanan Darah & Frekuensi & Persentase (\%) \\
\hline 1 & Pre Hipertensi & 8 & 26,7 \\
2 & Hipertensi Tahap 1 & 17 & 56,7 \\
3 & Hipertensi Tahap 2 & 5 & 16,7 \\
\hline \multicolumn{2}{l}{ Total } & 30 & $100,1(100,0)$ \\
\hline
\end{tabular}

Berdasarkan Tabel 2 diatas hipertensi tahap 1 sebanyak 17 orang dapat diketahui bahwa dari $30 \quad(56,7 \%)$ dan hipertensi tahap 2 responden di Puskesmas Sukamerindu sebanyak 10 orang (16,7\%) JNC 7 yang memiliki tekanan darah pre (2003). hipertensi sebanyak 8 orang $(26,7 \%)$, 
Tabel 3

Uji Normalitas

\begin{tabular}{ll|c|c|c}
\hline \multicolumn{3}{|c|}{ Tekanan Darah } & \multicolumn{3}{|c}{ Shapiro Wilk } \\
\cline { 3 - 5 } & Statistic & Df & Sig. \\
\hline $\begin{array}{l}\text { Sistolik Sebelum Minum Rebusan } \\
\text { Bunga Rosells }\end{array}$ & 0,868 & 30 & 0,002 \\
$\begin{array}{l}\text { Diastolik Sebelum Minum Rebusan } \\
\text { Bunga Rosella }\end{array}$ & 0,720 & 30 & 0,000 \\
$\begin{array}{l}\text { Sistolik Sesudah Minum Rebusan } \\
\text { Bunga Rosella }\end{array}$ & 0,949 & 30 & 0,162 \\
$\begin{array}{l}\text { Diastolik Sesudah } \\
\text { Bunga Rosella }\end{array}$ & 0,855 & 30 & 0,001 \\
\hline
\end{tabular}

Berdasarkan Tabel 3 di atas yang menggunakan uji Shapiro Wilk diketahui bahwa tekanan sistolik sebelum minum rebusan bunga rosells didapat hasil $p$-value $=0,002<0,05$, berarti data tidak berdistribusi normal, diastol sebelum minum rebusan bunga rosells didapat hasil p-value $0,000<0,05$, berarti data tidak berdistribusi normal, sistolik sesudah minum rebusan bunga rosells didapat hasil $p$-value $0,162>0,05$, berarti data berdistribusi normal dan diastolik sesudah minum rebusan bunga rosells didapat hasil p-value $0,001<0,05$, berarti data tidak berdistribusi normal.
Karena hanya satu kelompok data yang berdistribusi normal, sedangn tiga kelompok data yang lain tidak berdistribusi normal, maka uji Paired Sample T-Test tidak dapat digunakan selanjutnya akan digunakan uji statistik Wilcoxon Sign Rank Test.

\section{Analisis Bivariat}

Analisis Bivariat digunakan untuk mengetahui pengaruh penurunan tekanan darah sebelum dan sesudah pemberian rebusan bunga rosella di wilayah Puskesmas Sukamerindu Kota Bengkulu.

Tabel 4

Tabulasi Silang Tekanan Darah Sebelum dan Sesudah Perlakuan

\begin{tabular}{lcccc}
\hline \multirow{2}{*}{ Tekanan Darah } & \multicolumn{2}{c}{ Tekanan Darah Sesudah Perlakuan } & \\
\cline { 2 - 4 } Sebelum Perlakuan & Pre & Hipertensi & Hipertensi & \\
Hipertensi & Tahap 1 & Tahap 2 & Total \\
Pre Hipertensi & 1 & 0 & 0 & 1 \\
Hipertensi Tahap 1 & 7 & 12 & 0 & 19 \\
Hipertensi Tahap 2 & 0 & 5 & 5 & 10 \\
Total & 8 & 17 & 5 & 30 \\
\hline
\end{tabular}


Berdasarkan Tabel 4 tekanan darah sebelum perlakuan dari 30 responden didapatkan hasil bahwa responden yang mengalami pre hipertensi sebanyak 1 orang, hipertensi tahap 1 sebanyak 19 orang dan hipertensi tahap 2 sebanyak 10 orang.
Tekanan darah sesudah perlakuan dari 30 responden didapatkan hasil bahwa responden yang mengalami pre hipertensi sebanyak 8 orang, hipertensi tahap 1 sebanyak 17 orang dan hipertensi tahap 2 sebanyak 5 orang.

Tabel 5

Uji Wilcoxon Signed Ranks Test

\begin{tabular}{clllc}
\hline Tekanan Darah & \multicolumn{2}{c}{ Ranks } & Z & $\begin{array}{c}\text { p-Value (Asymp. } \\
\text { Sig. 2-tailed) }\end{array}$ \\
\hline Beda Tekanan & Negative Ranks & $: 24$ & & \\
Darah Sistolik & Positive Ranks & $: 0$ & & \\
sesudah -sebelum & Ties & $: 6$ & - & 0 \\
perlakuan & Total & $: 30$ & 4.293 & 0,000 \\
\hline Beda tekanan darah & Negative Ranks & $: 12$ & & \\
diastol sesudah - & Positive Ranks & $: 0$ & - & \multirow{2}{*}{0,002} \\
sebelum perlakuan & Ties & $: 18$ & 3.075 & \\
& Total & $: 30$ & & \\
\hline
\end{tabular}

Berdasarkan Tabel 5 pada tekanan darah sistolik sebelum dan sesudah perlakuan didapatkan hasil negative rank sebanyak 24 artinya terdapat penurunan tekanan darah sistolik, positive rank sebanyak 0 artinya tidak ada tekanan darah yang naik dan ties sebanyak 6 artinya tekanan darah sistoliknya tidak ada perubahan. Tekanan darah diastol sebelum dan sesudah perlakuan didapatkan hasil negative rank sebanyak 12 artinya terdapat penurunan darah diastol, positive rank sebanyak 0 artinya tidak ada tekanan darah diastol yang naik dan ties sebanyak 18 artinya tidak ada perubahan tekanan darah diastol.

Hasil tekanan darah sistolik sebelun dan sesudah perlakuan didapatkan nilai $Z=-4,293$ dengan $\mathrm{p}=$ value $=0,000<0,05$ berarti signifikan, maka Ho ditolak dan Ha diterima. Jadi Ada pengaruh pemberian rebusan bunga rosella terhadap penurunan tekanan darah sistolik pada pasien diwilayah kerja Puskesmas
Sukamerindu Kota Bengkulu. Hasil tekanan darah diastol sebelum dan sesudah perlakuam didapatkan nilai $\mathrm{Z}$ $=-3,075$ dengan $p=$ value $=0,002<0,05$ berarti signifikan, maka Ho ditolak dan $\mathrm{Ha}$ diterima. Jadi Ada pengaruh pemberian rebusan bunga rosella terhadap penurunan tekanan darah diastolik pada pasien diwilayah kerja Puskesmas Sukamerindu Kota Bengkulu.

\section{Pembahasan}

Hasil penelitian ini menemukan bahwa nilai uji Uji Wilcoxon Signed Ranks Test, didapatkanhasil tekanan darah sistolik sebelum dan sesudah perlakuan didapatkan nilai $\mathrm{Z}=-4,293$ dengan $\mathrm{p}=$ value $=0,000<0,05$ berarti signifikan, maka Ho ditolak dan $\mathrm{Ha}$ diterima. Jadi Ada pengaruh pemberian rebusan bunga rosella terhadap penurunan tekanan darah sistolik pada pasien diwilayah kerja Puskesmas Sukamerindu Kota Bengkulu. Hasil tekanan darah diastol sebelum dan sesudah perlakuam didapatkan nilai $\mathrm{Z}$ 
$=-3,075$ dengan $\mathrm{p}=$ value $=0,002<0,05$ berarti signifikan, maka Ho ditolak dan Ha diterima. Jadi Ada pengaruh pemberian rebusan bunga rosella terhadap penurunan tekanan darah diastolik pada pasien di wilayah kerja Puskesmas Sukamerindu Kota Bengkulu.

Hasil dari penelitian ini menunjukan bahwa pemberian rebusan bunga rosella ternyata dapat menurunkan tekanan darah sama seperti efek obat yang diberikan oleh dokter. Akan tetapi secara statistik pengaruh tersebut hanya menunjukan pengaruh yang lemah sama seperti pemberian obat. Kelemahan ini kemungkinan disebabkan kurangnya jumlah sampel. Walaupun menunjukan pengaruh yang lemah penelitian ini menunjukan hal yang serupa dengan penelitian yang dilakukan oleh Rohaendi (2008) yang melakukan penelitian tentang pengaruh Pemberian Teh Rosella Terhadap Tekanan Darah Pasien Hipertensi Primer di Panti Jompo Welas Asih Kota Tasikmalaya pada 31 pasien hipertensi dan 23 pasien sebagai kontrol. dengan lama intervensi 15 hari. Pada kelompok intervensi sebanyak $45 \%$ laki-laki dan $55 \%$ perempuan dengan usia $52.6+/-7.9$ tahun sedangkan pada kelompok kontrol $30 \%$ laki-laki dan $70 \%$ perempuan. Dengan usia $51.5+/-10.1$ tahun. Secara statistik ditemukan adanya penurunan tekanan darah sebanyak $11,2 \%$ untuk sistolik dan $10,7 \%$ untuk tekanan darah diastolik dalam waktu 12 hari dibandingkan pada saat hari pertama. Tiga hari setelah pemberia dihentikan, tekanan sistolik meningkat lagi $7,9 \%$ dan diastolik sebesar $5,6 \%$ pada kedua kelompok.

Selain itu penelitian lain yang dilakukan oleh Setiawan (2010) mengidentifikasi efek menurunkan lemak dan antioksidan dari rosella. Pada penelitian ini diberikan bunga kering rosella dengan dosis 500 sampai $1000 \mathrm{mg} / \mathrm{kg}$ selama 6 minggu, hasilnya menunjukan adanya penurunan kadar kolestrol yang mencolok sebesar 22$26 \%$ untuk serum kolestrol, 28-33\% untuk serum trigliserida dan 22-32\% untuk serum LDL. Kemampuan rebusan bunga rosella dalam menurunkan tekanan darah tidak terlepas dari kandungan rebusan rosella yang memiliki efek diuretik sehingga dapat menurunkan tekanan darah (Wright, 2004).

Penelitian bunga rosella juga dilakukan di Universitas Chung Shan Taiwan juga menunjukan pemberian rosella dapat menurunkan tekanan darah pada pasien sebesar $11 \%$ menurunkan kadar kolestrol dalam darah dan mencegah dari LDL. Pemberian rosella yang berisi $33.6 \mathrm{mg}$ antohocyanins per $120 \mathrm{mg}$ yang diberikan per oral selama 60 hari dapat menurunkan berat badan pada binatang percobaan (Aguilar et.al, 2005).

Obat yang diberikan pada penelitian ini adalah obat golongan kalsium antagonis berkerja pada membran plasma untuk menghalangi masuknya kalsium kedalam sel dengan memblok chanel kalsium tegantung. Ion kalsium memainkan peranan penting dalam kontraksi dari otot jantung, kerangka dan otot polos. Kalsium myoplasma tergantung pada masuknya kasium. Ikatan kalsium ikut mengatur troponin yang bergerak menghambat kerja dari tropomyosin, dan dengan adanya adenosin triphosphat menyebabkan intraksi antara myosin dan aktin yang menyebabkan adanya kotraksi otot sel. Pada penelitian ini diberikan obat dalam sub golongan Amlodipine besylate dengan nama dagang actrapin $5 \mathrm{mg}$. 


\section{E. Kesimpulan}

1. Penelitian ini telah mengidentifikasi beberapa karakteristik dari 30 responden. Jenis kelamin yang paling banyak mengikuti penelitian ini adalah perempuan. Dengan ratarata usia 32-48 tahun.

2. Rerata sebelum diberikan rebusan bunga rosella, diketahui bahwa dari 30 responden di Puskesmas Sukamerindu yang memiliki tekanan darah pre hipertensi sebanyak 1 orang $(3,3 \%)$, hipertensi tahap 1 sebanyak 19 orang $(63,3 \%)$ dan hipertensi tahap 2 sebanyak 10 orang $(33,3 \%)$. Dengan persentase 99,9 dengan total maksimal 100 .

3. Rerata sesudah pemberian rebusan bunga rosella, diketahui bahwa dari 30 responden di Puskesmas Sukamerindu yang memiliki tekanan darah pre hipertensi sebanyak 8 orang $(26,7 \%)$, hipertensi tahap 1 sebanyak 17 orang $(56,7 \%)$ dan hipertensi tahap 2 sebanyak 10 orang $(16,7 \%)$. Dengan persentase 100,1 dengan total yang sangat baik.

\section{Daftar Pustaka}

Adi, P.H. (2013). Efektifitas Bunga Rosella untuk Penurunan Tekanan Darah pada Pasien Hipertensi. Ponorogo: Universitas Muhammadiyah.

Aguilar C, et al. (2005). Topoisomarase II Suppresses The Temperature Sensitivity Of Saccharomyces Cerevisiae Pds5 Mutants, But Not The Defect In Sister Chromatid Cohesion. Cell Cycle, 4(9): 294-304.

Dinkes Provinsi Bengkulu. (2010), Profil Kesehatan Provinsi Bengkulu. Bengkulu : Dinkes Provinsi Bengkulu.

Kemenkes RI. (2013). Infodatin: Hipertensi. Jakarta: Pusat Data dan Informasi Kemenkes RI.
Maryani \& Kristiana. (2005).Khasiat dan Manfaat Rosela, Jakarta: Agromedia Pustaka.

Rohaendi, H. (2008). Pengaruh Pemberian Teh Rosella Terhadap Tekanan Darah Pasien Hipertensi Primer Dipanti Jompo Welas Asih Kota Tasikmalaya. Tesis. Fakultas Ilmu Keperawatan Universitas Indonesia.

Setiawan, R. (2010). Pengaruh Pemberian Ekstrak Kelopak Rosella (Hisbiscus Sabdariffa ) terhadap Penurunan Kadar Gula Darah Tikus Putih (Rattus Norvegicus) yan Diinduksi Aloksan. Skripsi. Fakultas Kedokteran Universitas Sebelas Maret.

Sustrani, L. (2006)._Hipertensi. Jakarta : PT Gramedia Pustaka.

WHO. (2003). Clinical Guidelines for Management of Hypertension. Cairo.

Wright, T.A. (2004). State And Trait Correlates of Job Performance. Journal of Business and Psychology, 18, 365-388. 